\title{
A Tentative Study on the Task-Based Teaching of Writing to English Majors in Chinese Settings
}

\author{
Sun Zhaochun ${ }^{1}$ \\ ${ }^{1}$ School of English for International Business, Guangdong University of Foreign Studies, Guangzhou, China \\ Correspondence: Sun Zhaochun, School of English for International Business, Guangdong University of Foreign \\ Studies, No.2 Baiyun Avenue North, Guangzhou, Guangdong, China. E-mail: allenzephyr@hotmail.com
}

Received: December 16, 2014 Accepted: January 20, 2015 Online Published: February 13, 2015

doi:10.5539/elt.v8n3p71 URL: http://dx.doi.org/10.5539/elt.v8n3p71

\begin{abstract}
Under task-based learning (TBL) framework, language learners engage in purposeful, problem-oriented, and outcome-driven tasks that are comparable to traditional teaching methods which focus only on the correctness of grammar. In this study, the author employs Jane Willis' TBL framework and examines its effects on the improvement of EFL learners' writing competence when such a framework is applied to English writing course for English majors in Chinese EFL context. The study results are derived from quantitative data yielded from experiments designed for this research. The findings of this research reveal that the application of TBL framework to English writing classrooms in Chinese EFL settings is effective in improving English majors' writing competence and performance. This study provides the teaching of EFL writing a feasible and effective approach.
\end{abstract}

Keywords: task-based approach, teaching of EFL writing, English majors

\section{Introduction}

Chinese English majors are required to learn English for four years according to the syllabus of Chinese State Ministry of Education. After four years of professional training, most English majors have a good command of English language. Among the four basic skills (listening, speaking, reading, and writing), the most difficult for English majors is writing, which can be seen from their scores in English language tests, such as IELTS, TOEFL, and TEM (Test for English Majors). How to improve students' writing competence has become the biggest concern for both English teachers and researchers. Task-based language teaching has been advocated as a means of promoting language learning in language classrooms in different settings (Branden, Gorp, \& Verhelst, 2007; Eckerth \& Siekmann, 2008; Samuda \& Bygate, 2008; Van den Branden, 2006) and has become a prominent research focus in the last decade (Adams, 2009; Ellis, 2003). According to Adams (2009), task-based language teaching has been practiced at the nexus of theories including input processing (Van Patten, 1996), information process (Levelt, 1989), the interactionist approach (Mackey \& Gass, 2006), and neo-Vogotskian socio-cultural theory (Lantolf, 2000a). This study adopts Jane Willis' TBL framework (Willis, 1996) to organize activities in English writing classrooms to test whether TBL method can improve writing competence of English majors based on quantitative data yielded from our study in which an experimental class and a control class are designated randomly. In this study, we aim to address two issues: 1) Will the adoption of TBL framework in the teaching of writing improve English majors' writing competence; 2) Is TBL method more effective than traditional teaching methods?

\section{Significance of the Study}

\subsection{Theoretical Significance}

In the English writing classrooms in Chinese EFL context, two main teaching approaches or pedagogies are commonly practiced: the "product-oriented approach" and "process-oriented approach". The former focuses on the "the final product, the coherent, error-free text"; while the latter places its emphasis on "the steps involved in drafting and redrafting a piece of work" (Nunan, 2001, p. 272). However, since both approaches have shortcomings and limitations, there is no convincing evidence on which approach is more effective in improving learners' writing competence. TBL approach is expected to transcend the limitations in that "both processes and outcomes are taken care of" and furthermore, "there is a compatible and creative relationship between the two" 
(Nunan, 1989, p. 14). Different from the "product-oriented approach" and the "process-oriented approach", the TBL method takes into account the writing process and the final products as well. Nevertheless, apart from the theoretical exploration of TBL language pedagogy, the practice and investigation of TBL method in the teaching of English writing are still wanting.

\subsection{Practical Significance}

In English writing classrooms in Chinese settings, one of the dominant "product-oriented" teaching models is known as 3Ps approach: presentation, practice, and production. At the first stage, teachers present prose models or certain grammatical rules or important sentence patterns to students, the aim of which is to impart language knowledge to students. At the second stage, the students have some practice activities to automatize the newly taught language knowledge. At the final stage, the students are required to accomplish an essay assignment and the teachers give corrections to the grammatical and wording errors and write comments on the assignment. The popularity of the 3Ps approach can be explained by two reasons. For one reason, it is easy to conduct in writing class and can keep the dignity of teachers. For another reason, it is based on the input-output hypothesis, which claims that language learners have to receive enough input before they are able to produce the output in the target language. However, the 3Ps approach has its drawbacks. First, both the teachers and the learners are much concerned about the end product, neglecting the content and ideas of writing. Second, the exercises in class are usually dull and the students cannot decide the topics they want to write. As a result, the writing classes are boring and cannot arouse students' interest in writing. Finally, the link between input and output is not as strong as it is supposed to; furthermore, input does not necessarily lead to output since input does not equal intake.

In addition to the "product-oriented" teaching model, the "process-oriented" approach is also practiced in English writing classrooms in Chinese settings. Different from the "product-oriented" approach, the "process-oriented" approach focuses on the process of contemplating ideas and making meanings itself rather than the final product (Susser, 1994). Teachers are not expected to solely review or score the final product. Instead, they should help students to solve writing difficulties through working with them to discover and organize ideas, express themselves, and revise their writing through drafts. The theoretical background for the "process-oriented" approach is "cooperative learning", which believes that through group learning activities each learner of a group can exchange information to motivate and improve each others' learning outcome (Olsen \& Kagan, 1992). However, this approach is not widely adopted in the English writing classrooms. One reason is that the topics and the long duration of the writing process are difficult to control. Another reason lies in the fact that it neglects the grammatical accuracy of writing.

Compared with the "product-oriented" approach and the "process-oriented" approach, the task-based approach advocates that all the language skills should be integrated in the process of learning and teaching. According to Nunan (2004), tasked-based teaching focuses not only on communicating through interaction in the target language, but also on grammatical accuracy and forms. It is expected to overcome the shortcomings of the traditional English writing approaches.

\section{The Task-Based Approach to EFL Teaching}

\subsection{Introduction to the Task-Based Approach}

The concept of task-based learning and teaching comes from adult vocational education. It has been used in foreign language teaching classrooms since the mid-1970s, and the term "task" came into deliberate use in the early 1980s. There are many definitions of "task". Nunan (1989) defines "task" as "a piece of classroom work which involves learners in comprehending, manipulation, producing or interacting in the target language". Ellis (2003) defines "task" as "a work plan that requires learners to process language pragmatically". Willis (1996) defines "task" as "tasks are always activities where the target language is used by the learner for a communicative purpose (goal) in order to achieve an outcome". No matter how many definitions there are, a task usually includes the following five components: 1) a purpose of underlying real-life justification for doing the task that involves more than simply displaying knowledge or practicing skills; 2) a context in which the task takes place that may be real, simulated, or imaginary; 3) a process of thinking and doing; 4) a product or the result of thinking and doing; and 5) a framework of knowledge and skills (Clark, Scarino, \& Brownell, 1994).

In this study, we adopt Willis' TBL framework as our research methodology in the task-based language teaching. According to Willis (1996, p. 53), task-based classroom activities are composed of three stages: "pre-task", "task cycle" and "language focus". In the first phase, the learners make some preparations for a specific task. The teachers prime the students with some useful words and phrases and present a model of the task by either doing it themselves or by presenting pictures, playing audios or video demonstrating the task. In the second phase, the students are divided into groups. In each group, the students discuss the task orally while the teacher monitors 
from a distance. The teacher acts as an observer or a counselor to guarantee the student-centered learning. After discussion, the students are required to make an outline and some notes. The first draftsare required to be finished within each study group in the required time. Then, the drafts are exchanged with other study groups for suggestions. The learners can review each other's work and offer constructive feedback. After that, each study group will be required to revise the first drafts and make ready the final drafts. In the third phase, some groups in the class will be designated to make a report to the class, sharing with the whole class what they have explored and learnt from their collaboration of the task. Meanwhile, the teachers sum up the language points in the task. The TBL framework advocates not only fluency and spontaneity of language use, but also the accuracy of language form. This is the reason why the TBL framework is influential in language teaching.

\subsection{Relevant Researches}

Recent years have seen an enormous growth of interest in task-based language learning and teaching (Willis, 1996; Skehan, 1996, 1998; Bygate, Skehan, \& Swain, 2000; Ellis, 2000, 2006). Willis (1996) proposes a 3-step sequence for task-based leaning. The sequence, as Willis characterizes it, has resemblances with the traditional 3Ps but in the reverse order. Willis' approach is a new attempt to apply the underlying principles of TBL framework tolanguage teaching. As for how to implement TBL in writing courses, Willis doesn't go into the details. Skehen $(1996,1998)$ clarified the definition and the characteristics of task-based learning. He also gave some pedagogic proposals and future directions of it. Ellis (2000) makes great effort to discuss task and language pedagogy from psycholinguistic and socio-cultural perspectives. Ellis (2006) further discusses the procedures relating to how tasks specified in a task-based syllabus can be converted into actual lessons and how the teacher and learners are to participate in the lessons. In addition to the theoretical exploration of task-based learning and language pedagogy, there are a bunch of empirical studies on the effectiveness of the TBL approach in language learning and teaching. Sofia (2013) employed TBL approach to teach technical writing for students of engineering in Indian settings with the help of two collaborative Web 2.0 tools-Google Drive and Blogs. The findings in this study show that the TBL approach enhanced the writing competence for students. Neda and Aliye (2013) adopted the TBL approach in English writing and reading in Iranian settings. The results of their study prove that the TBL approach has a positive influence on EFL learners' writing and reading performances. Narjess and Sayyed (2013) applied the TBL approach to writing classes for Iranian EFL learners. The results reveal that pre-task planning is an effective writing strategy and plays a crucial role in boosting EFL learners' general writing ability when completing personal and decision-making tasks.

Apart from the studies conducted in other language settings, task-based learning has also aroused the teachers' interest in English language teaching in Chinese settings (Cai, 2001; Zhu, 2002; Cao, 2012; Miao, 2014). Cao (2012) studies the feasibility of Willis' TBL framework applied to Chinese EFL learners and proves that TBL is an effective approach to improve EFL learners' writing competence, using qualitative and quantitative data. Miao (2014) applies task-based learning in big English writing classes for Chinese EFL learners and shows positive effect of TBL approach. So far, all the researches are on college EFL learners of other majors rather than English majors. Our study can be probably considered as the first attempt to study the effect of TBL approach on English majors in Chinese settings.

\section{Methodology}

\subsection{Subjects}

In this study, two intact parallel classes in the School of English for International Business, Guangdong University of Foreign Studies were chosen randomly as a control class and an experimental class. There were 25 subjects in each class. All the 50 subjects were sophomores and they had studied English for 10 years $(9$ years before they entered the college and 1 year after they entered the college). Their ages ranged from 19 to 21 . Their enrollment was based on their overall score of the College Entrance Exam (a nationwide exam for college admission in China) administered by Guangdong Education and Exam Academy. Generally speaking, the education background of the 50 subjects was fairly homogeneous and their English level was nearly the same.

\subsection{Experimental Design}

Considering the purpose of the study, we designated two classes to participate in the study: One class was the control class and the other class was the experimental class. The treatments to the two classes were different: in the control class we adopted the traditional teaching method-the 3Ps approach, while in the experimental class we adopted Willis' TBL approach. Thus, the treatments to the two classes-the teaching methods were the independent variable, and the effects of the treatments on the learners' writing competence were the dependent variable. As we know, apart from the teaching methods, other factors, such as age, education level, motivation, 
years of English study, etc., have an effect on the learners' writing competence. To keep these factors from taking effect and guarantee a single-factor experiment, we had strict control over them.

\subsection{Procedures}

According to the syllabus, the sophomores have to complete a 16-week English writing course (80 minutes per week) in the first semester of the second academic year. Our study was conducted from September 2012 to January 2013. During the 16-week writing course, the students had to complete 8 writing tasks, including 1 pretest, 1 posttest and 6 essay assignments. We gave different treatments to the two classes during the practice of teaching: in the control class, we adopted the traditional 3Ps approach; while in the experimental class, we adopted Willis' TBL approach. Except for this difference, all other factors remained intact.

\section{Data Acquisition}

\subsection{Quantitative Data}

The quantitative data in this study include the scores of three tests: the "Comprehensive English Final Test (CEFT)" in the second semester of the first academic year, the pretest and the posttest. The score of the CEFT was used to testify whether the subjects were of the same English level before they participated in the experiment. CEFT is a hundred-mark test, which is composed of the following parts: listening, vocabulary \& grammar, reading comprehension, proof reading, cloze, and Chinese-English translation. The score of CEFT can represent the subjects' comprehensive English language competence before they participated in this study.

Before the experiment, we gave the subjects in the control class and the experimental class a pretest to guarantee that they were of the same writing competence. To testify whether the adoption of Jane Willis' TBL framework in writing classes can improve learners' writing competence, we gave the subjects a posttest at the end of the experiment. The pretest and the posttest were two writing tasks. The subjects were required to write an essay of no fewer than 250 words in 40 minutes in each task. To guarantee the validity of the experiment, the difficulty of the two tasks remained the same. The essays were rated in accordance with the scoring criteria by two experienced lecturers in the School of English for International Business, Guangdong University of Foreign studies. The scores of the pretest and the posttest were used for cross-sectional and longitudinal study. After the scores of the three tests were collected, the Statistical Package for the Social Science (SPSS16.0) was used as a tool to analyze the data.

\subsection{Scoring Criteria and Methods}

In this research, we adopted the essay writing assessment rubrics of Test for English Majors band 4 (TEM4) as our scoring criteria. TEM4 is a nationwide compulsory test for the sophomores of English majors in China and a prerequisite for the degree of BA. It has been practiced for more than 20 years aiming at testing the language competence and proficiency for English majors. The total score of TEM4 essay writing is 15 points. The assessment is made from three aspects: "ideas \& evidence", "communicative quality", and "vocabulary \& expressions", which can reflect the real writing competence of the examinees. The reason we adopted TEM4 assessment rubrics as our scoring criteria is that the two raters have years of experience of scoring TEM4 essay writing; therefore, they have a good command of the scoring criteria. Based on the scoring criteria, each of the two raters gave a holistic score to the pretest and posttest. The final score of the pretest and the posttest was the average of the scores given by Rater A and Rater B.

\section{Results}

\subsection{CEFT}

The scores of CEFT in the second semester of the first academic yearare used to testify whether the subjects in the control class and the experimental class were of the same English level before they participated in this experiment.The descriptive statistics in Table 1 show that the mean scores of the two classes were approximately the same. Thus, it is ensured that the subjects in the two classes were at the same English level.

Table 1. Results of CEFT

\begin{tabular}{llllll}
\hline Classes & $\mathrm{N}$ & Lowest score & Highest score & Mean & S.D. \\
\hline Control & 25 & 62 & 87 & 78.88 & 6.30 \\
Experimental & 25 & 65 & 89 & 77.84 & 6.52 \\
\hline
\end{tabular}




\subsection{Pretest}

Although the subjects of the control class and the experimental class were at the same English level, it is still unknown whether the subjects in the two classes were at the same writing level. To testify this, the subjects in the two classes were given a pretest in Sep. 2012 before the experiment. The purposes of the pretest are twofold. On the one hand, it can testify whether the subjects in the control class and the experimental class were at the same writing level before they participated in the experiment. On the other hand, it can be compared with the posttest to see whether the subjects made any improvement in writing competence at the end of the experiment. To ensure that the scores given by rater A and those given by rater B had a strong correlation, we conducted an inter-rater reliability analysis. According to the $r$ value of Pearson Correlation Coefficient in Table $2(r=0.747)$, we get a $r_{A B}$ value $\left(r_{A B}=0.86\right)$, which indicates a strong correlation between the scores given by the two raters.

Table 2. Pretest correlation of rater A and rater B

\begin{tabular}{llll}
\hline & & Rater A (Pretest) & Rater B (Pretest) \\
\hline Rater A (Pretest) & Pearson Correlation & 1.000 & $.747^{* *}$ \\
& Sig. (2-tailed) & & .000 \\
& N & 50 & 50 \\
Rater B (Pretest) & Pearson Correlation & $.747^{* *}$ & 1.000 \\
& Sig. (2-tailed) & .000 & \\
& N & 50 & 50 \\
\hline
\end{tabular}

**. Correlation is significant at the 0.01 level (2-tailed).

Given that there is a strong correlation between the scores given by the two raters, we then conducted an independent samples t-test to testify whether there is any significant difference between the control class and the experimental class in the pretest.

Table 3. Independent samples t-test of the pretest

\begin{tabular}{lllllll}
\hline & $\mathrm{N}$ & Mean & S.D. & $\mathrm{t}$ & $\mathrm{df}$ & Sig. (2-tailed) \\
\hline Control class & 25 & 9.38 & 1.3092 & \multirow{2}{*}{0.497} & \multirow{2}{*}{48} & \multirow{2}{*}{0.621} \\
Experimental class & 25 & 9.22 & 0.9363 & & & \\
\hline
\end{tabular}

As is shown in Table 3, no significant difference is found between the control group and the experimental group in terms of the mean score $(\mathrm{t}=0.497$; P $($ Sig. $)=0.621>0.05)$. Statistics from Table 3 show that before the experiment the writing competence of the subjects in the control group and the experimental group was the same.

\subsection{Posttest}

After learning English writing for 16 weeks, the subjects in the control class and the experimental class were given a posttest in Jan. 2013. Although the scoring criteria and the raters of the posttest remained unchanged, we still need to check the inter-rater reliability.

According to the $r$ value of Pearson Correlation Coefficient in Table $4(r=0.587)$, we get a $r_{A B}$ value $\left(r_{A B}=0.74\right)$. Again, there is a strong correlation between the scores given by the two raters. Then, we conducted several t-tests within group and between groups. Firstly, a paired samples t-test was conducted separately in the control group and the experimental group (Table 5, Table 6). In each group, we compared the scores of the pretest and the posttest to testify whether the subjects made any improvement after the 16-week writing course. Secondly, to testify whether the adoption of Willis' TBL framework in the writing class is more effective than the traditional 3Ps approach in improving learners' writing competence and performance, an independent samples t-test was conducted between the control group and the experimental group (Table 7). 
Table 4. Posttest correlation of rater A and rater B

\begin{tabular}{llll}
\hline & & Rater A (Posttest) & Rater B (Posttest) \\
\hline Rater A (Posttest) & Pearson Correlation & 1.000 & $.587^{* *}$ \\
& Sig. (2-tailed) & & .000 \\
& $\mathrm{~N}$ & 50 & 50 \\
Rater B (Posttest) & Pearson Correlation & $.563^{* *}$ & 1.000 \\
& Sig. (2-tailed) & .000 & \\
& $\mathrm{~N}$ & 50 & 50
\end{tabular}

**. Correlation is significant at the 0.01 level (2-tailed)

Table 5. Paired samples t-test for the control class

\begin{tabular}{llllllll}
\hline & $\mathrm{N}$ & Mean & S.D. & Mean Difference & $\mathrm{t}$ & $\mathrm{df}$ & Sig. (2-tailed) \\
\hline Pretest & 25 & 9.3800 & 1.3092 & -0.4200 & -3.055 & 24 & 0.005 \\
Posttest & 25 & 9.8000 & 0.9013 & & & & \\
\hline
\end{tabular}

Table 6. Paired samples t-test for the experimental class

\begin{tabular}{llllllll}
\hline & $\mathrm{N}$ & Mean & S.D. & Mean Difference & $\mathrm{t}$ & $\mathrm{df}$ & Sig. (2-tailed) \\
\hline Pretest & 25 & 9.2200 & 0.9363 & -1.1200 & -12.736 & 24 & 0.000 \\
Posttest & 25 & 10.3400 & 0.8504 & & & & \\
\hline
\end{tabular}

The statistics in Table 5 and Table 6 show that the difference in the comparison between the pretest and the posttest is significant in both the control class $(\mathrm{t}=-3.055, \mathrm{P}=0.005<0.05)$ and the experimental class $(\mathrm{t}=$ $-1.1200, \mathrm{P}=0.000<0.05$ ). The results indicate that the subjects both in the control class and in the experimental class made improvement in the writing competence after 16 weeks' learning of English writing. According to the mean scores, it can be found that the improvement of the experimental class is larger than that of the control class.

Table 7. Posttest independent samples t-test

\begin{tabular}{lllllll}
\hline & $\mathrm{N}$ & Mean & S.D. & $\mathrm{t}$ & $\mathrm{df}$ & Sig. (2-tailed) \\
\hline Control class & 25 & 9.8000 & 0.9013 & \multirow{2}{*}{-2.179} & 48 & \multirow{2}{*}{0.034} \\
Experimental class & 25 & 10.3400 & 0.8504 & & & \\
\hline
\end{tabular}

The statistics in Table 7 show that the difference in the posttest in the comparison between the control class and the experimental class $(t=-2.179, \mathrm{P}=0.034<0.05)$ is also significant. This result verifies that the adoption of Willis' TBL framework in the writing class is more effective than the traditional 3Ps approach in improving English majors' writing competence.

\section{Discussion}

In this study, we designed two research questions: 1) Will the adoption of Willis' TBL approach in the English writing classes improve the learners' writing competence; 2) Is the TBL approach more effective than traditional teaching approaches? From the results of the longitudinal and cross-sectional study, the answer to both the questions is affirmative. Our findings are consistent with Cao (2012) and Miao (2014).The TBL approach has proved to be an effective method to teach English writing to EFL learners.

The application of the TBL approach has brought about some changes to the writing classes. Firstly, it has converted the EFL learners' role from a passive receiver to an active participant. According to our random interviews with the students in the experimental class, the learners are more willing to partake in the discussion and debate with their classmates. Discussion and debate provide good opportunities for the learners to share 
knowledge and broaden perspectives. We are now in an information age, but face-to-face discussion and conversation is still the most effective way for people to acquire information and knowledge. Secondly, the TBL approach has converted the teachers' image from a rigid instructorto an amiable director. Thanks to the influence of the traditional teaching methods and Confucius teaching philosophy, the image of the teachers in Chinese settings is serious, authoritative, and unchallengeable. In teachers' eyes, good students are those who are obedient and raise no questions. In such a context, most students are unwilling or feared to ask questions to the teachers in class; accordingly, their queries cannot be solved in time. The conversion of the teachers' role in the TBL approach has provided the students with an environment where they can ask questions to their peers and to the teachers. Consequently, the learners can promptly solve the questions they meet in their study and improve their writing competence with the help of others.

Compared with the TBL approach, the traditional 3Ps approach has not brought about apparent changes to the writing class in terms of the study environment and learners' participation, even though it has positive effects in improving the learners' writing competence. According to the random interviews with the students in the control class, the learners are lacking in study motivation and confidence. They feel that writing classes are boring and dreary in comparison with speaking and other classes. They aspire for some changes in the writing classes, though they believe that their writing competence had been improved after they completed the course.

Apart from the findings mentioned above, some other differences between the control class and the experimental class are observed. Firstly, the length of the essays by the subjects in the experimental class was much longer than that by the subjects in the control class. Take the posttest as an example. The average word number of the essays in the experimental class was 302 , while it was 265 in the control class. This may be explained by study motivation. In the experimental class, the subjects maintained high morale through in-class activities, such as brainstorming, discussion, idea sharing, and presentation, whereas the void of such activities in the control class could not stimulate the learners' study motivation and interest. Secondly, the learners in the experimental class paid more attention to word collocations. In the posttest, we examined five words (argument, belief, idea, issue, opinion) and their collocations. We found that the subjects in the experimental class used a variety of collocations. Take the word "argument" as an example. We found 6 adjectives (convincing, flimsy, well-grounded, coercible, solid, well-knit) and 5 verbs (present, put forward, support, refute, agree with) collocated with "argument". However, in the control class, only 3 adjectives (convincing, reasonable, solid) and 2 verbs (put forward, support) were found collocated with "argument". This contrast illustrates that the subjects in the experimental class had a better command of word knowledge with respect to accuracy and collocation. The knowledge of word collocation is one of the results of in-class discussion and idea sharing.

All the evidence points to the fact that the adoption of Willis' TBL approach has positive effect in improving learners' writing competence and that Willis' TBL approach is more effective than the traditional 3Ps approach. Based on the precondition that all the factors of the subjects other than the pedagogical treatments were well controlled, we can conclude that the differences of writing competence and performance of the learners were the result of different pedagogical treatments.

\section{Conclusion}

This research is a tentative study on the effectiveness of TBL approach in the English writing class. The TBL approach, combining "product-oriented" approach and "process-oriented" approach, is supposed to overcome the problems and difficulty encountered by the traditional writing approaches. The results from the research show that TBL approach is more effective in improving learners' English writing competence than other approaches. The improvement is not only reflected from the test scores, but also from the length of essays, the awareness of collocations and wording accuracy. Apart from the quantitative evidence, there is other supporting evidence to show that the TBL approach brings about changes in terms of the learners' study motivation and interest. In the TBL framework, the stereotyped "teacher-centered" approach is replaced by "learner-centered" approach. The activities in class, such as discussion, presentation, suggestion, can arouse learners' study interest. The suggestions from the peer students can help improve the quality of writing. All in all, the TBL approach in the English writing class has positive effects in improving EFL learners in Chinese setting.

\section{Limitations}

There is no denying the fact that there are some limitations in this study, though the findings of it are positive.

1) Apart from the pretest and the posttest, the 50 subjects in the experiment were required to submit 6 other essays as assignments during the 3 -month writing course. The assignments were completed partially in class and partially after class. Therefore, the time spent on the assignments after class is beyond our control. It is possible 
that the subjects in the experimental class spent more time on the assignments owing to high study motivation than the control class.

2) The 50 subjects in the experiment are all English majors in the School of English for International Business. In the second academic year, they have different orientations, such as Management, International Trade, International Business, etc., which means that the total time spent on English learning differs accordingly. This difference may affect their English competence more or less.

3) Though we have well-designed teaching plan, the fact is that more often than not the in-class activities such as discussion, report, and presentation are not well controlled because of the complexity and difficult of topics. Some activities have to be accomplished after class. The time spent on after-class activities and effect cannot be monitored and controlled.

In conclusion, the TBL approach is a new teaching pedagogy. The research on it is still wanting. Considering the limitations of our study, the feasibility and the effect of it need further study and in-depth exploration. Further researches are suggested to take other factors such as learners' attitude, motivation, etc. into consideration. They are bound to add the literature on TBL approach in English language teaching and learning.

\section{References}

Adams, R. (2009). Recent publications on task-based language teaching: A review. International Journal of Applied Linguistics, 19(3), 339-355. http://dx.doi.org/10.1111/j.1473-4192.2009.00239.x

Branden, K. V. D., Gorp, K. V., \& Verhelst, M. (Eds.). (2007). Tasks in action: Task-based language education from a classroom-based perspective. Newcastle: Cambridge Scholars Press.

Bygate, M., Skehen, P., \& Swain, M. (Eds.). (2000). Researching Pedagogical Tasks: Second Language Learning, Teaching and Testing. Essex: Longman.

Cai, L. Z. (2001). Application of task-based learning in English writing. Foreign Language Circle Journal, 4, $18-22$.

Cao, L. (2012). A feasibility study of task-based teaching of college English writing in Chinese EFL context. English Language Teaching, 5(10), 80-91. http://dx.doi.org/10.5539/elt.v5n10p80

Clark, J., Scarino, A., \& Brownell, J. (1994). Improving the quality of learning: A framework for Target-Oriented Curriculum Renewal. Hong Kong SAR, China: Institute of Language in Education.

Eckerth, J., \& Siekmann, S. (2008). Task-based language learning and teaching. Frankfurt am Main: Lang.

Ellis, R. (2000). Task-based research and language pedagogy. Language Teaching Research, 4(3), 193-220. http://dx.doi.org/10.1177/136216880000400302

Ellis, R. (2003). Task-based language learning and teaching. Oxford: Oxford University Press.

Ellis, R. (2006). The methodology of task-based teaching. Asian EFL Journal, 8(3), 19-45. Special Conference Proceedings Volume: Task-based Learning in the Asian Context.

Lantolf, J. P. (2000a). Second language learning as a mediated process. Language Teaching, 33(2), 79-96. http://dx.doi.org/10.1017/s0261444800015329

Levelt, W. (1989). Speaking: From intention to articulation. Cambridge, UK: Cambridge University Press.

Mackey, A., \& Gass, S. (2006). Pushing the methodological boundaries in interaction research: An introduction to the special issue. Studies in Second Language Acquisition, 28(2), 167-178. http://dx.doi.org/10.1017/s027 22631060086

Miao, H. (2014). The task-based teaching of writing to big classed in Chinese EFL setting. English Language Teaching, 7(3), 63-70. http://dx.doi.org/10.5539/elt.v7n3p63

Narjess, A. T., \& Sayyed, M. A. (2013). A comparative study of the effects of task-based writing under different pre-task planning conditions on Intermediate EFL learners' written performance in personal and decision-making tasks. International Research Journal of Applied and Basic Sciences, 5(8), 970-978.

Neda, F. R., \& Aliye, M. J. (2013). Teaching English and task-based method. International Journal of English Language and Literature Studies, 2(2), 87-94.

Nunan, D. (1989). Designing Tasks for the Communicative Classroom. Cambridge: Cambridge University Press.

Nunan, D. (2001). Second Language Teaching and Learning. Beijing: Foreign Language Teaching and Research Press. 
Nunan, D. (2004). Task-based language teaching. Cambridge: Cambridge University Press.

Olsen, R., \& Kagan, S. (1992). About cooperative leaning. In C. Kessler (Ed.), Cooperative language learning: A teacher's resource book (pp. 1-30). Englewood Cliffs, NJ: Prentice Hall.

Samuda, V., \& Bygate, M. (2008). Tasks in second language learning. Basingstoke: Palgrave Macmillan.

Skehan, P. (1996). A framework for the implementation of task-based instruction. Applied Linguistics, 17, 38-62. http://dx.doi.org/10.1093/aplin/17.1.38.

Skehan, P. (1998). Task-based instruction. Annual Review of Applied Linguistics, 18, 268-286. Retrieved from http://faculty.ksu.edu.sa/yousif/3422/Task-based\%20instruction,\%20Skehan,\%202003.pdf

Sofia, H. (2013). Employing task-based approach to teach technical writing for students of engineering using Web2.0 tools. International Journal of English and Literature, 3(5), 7-20.

Susser, B. (1994). Process approaches in ESL/EFL writing instruction. Journal of Second Language Writing, 3 , $31-47$.

Van den Branden, K. (Ed.). (2006). Task-based language teaching: From theory to practice. Cambridge: Cambridge University Press.

Van Patten, B. (1996). Input processing and grammar instruction in second language acquisition. Norwood, NJ: Ablex.

Willis, J. (1996). A Framework for Task-based Learning. London: Longman.

Zhu, M., \& Liu, H. Q. (2002). Application of task-based learning in teaching of English writing. Journal of Hebei Agricultural University, 4, 25-30.

\section{Copyrights}

Copyright for this article is retained by the author(s), with first publication rights granted to the journal.

This is an open-access article distributed under the terms and conditions of the Creative Commons Attribution license (http://creativecommons.org/licenses/by/3.0/). 